\title{
Pemodelan Implementasi Produksi Bersih pada Industri Pengasapan Ikan Pari Skala UMKM di Sentra Ikan Bulak, Kota Surabaya
}

\author{
Jennie Yuwono, Cahyono Susetyo \\ Departemen Perencanaan Wilayah dan Kota, Fakultas Teknik Sipil dan Perencanaan, Institut \\ Teknologi Sepuluh Nopember (ITS) \\ e-mail: cahyono_s@urplan.its.ac.id
}

\begin{abstract}
Abstrak-Kegiatan pengasapan ikan ditengarai menjadi penyebab menurunnya kualitas perairan Kenjeran, Kota Surabaya. Untuk mencegah kerusakan yang lebih parah, solusi yang dapat dilakukan adalah dengan mengatur pembuangan sisa pembersihan ikan. Saat ini kegiatan pengasapan ikan yang terkonsentrasi di Sentra Ikan Bulak (SIB), Kecamatan Bulak, sudah menerapkan produksi bersih secara sederhana. Penelitian ini bertujuan untuk mengetahui seberapa besar potensi nilai penjualan yang dihasilkan oleh industri pengasapan ikan pari di SIB yang telah menerapkan produksi bersih melalui pemodelan dengan system dynamics. Sampel diambil sebanyak 17 unit usaha pengasapan ikan pari yang beroperasi di Sentra Ikan Bulak. Validasi dilakukan dengan cara uji RMSE. Dari hasil simulasi dengan sistem dapat diketahui bahwa: (1) proses pengasapan meningkatkan nilai penjualan ikan pari sebesar $27 \%$ dibandingkan ikan pari yang dijual tanpa mengalami proses pengasapan; (2) nilai dari penjualan limbah yang memiliki nilai ekonomis (limbah kulit pari dan arang batok) berkontribusi sebesar $39,96 \%$ terhadap nilai penjualan total produk industri pengasapan ikan pari; (3) nilai penjualan limbah mampu meningkatkan nilai penjualan ikan pari asap sebesar $58 \%$.
\end{abstract}

Kata Kunci-ikan pari, pengasapan ikan, produksi bersih, Sentra Ikan Bulak, system dynamics.

\section{PENDAHULUAN}

$I_{k}^{N}$ NDUSTRI pengolahan ikan dapat dikatakan sebagai kegiatan yang memiliki kompleksitas yang tinggi karena melibatkan upaya penangkapan - yang antara lain dipengaruhi oleh musim melaut, harga bahan bakar minyak (BBM), populasi ikan, dll -, keunikan proses pengolahan karena komposisi biologis tubuh ikan [1] maupun tingkat konsumsi air dan potensi timbulan limbah yang tinggi sehingga produksi bersih perlu diterapkan pada industri ini [2] [1]. Di Indonesia, industri pengolahan ikan adalah kegiatan yang gencar dikembangkan mengingat Indonesia memiliki potensi di bidang perikanan, khususnya perikanan tangkap, yang tinggi karena kondisi geografis Indonesia yang terdiri atas wilayah perairan sebesar 70\%. Kelimpahan jenis ikan di Indonesia pun tergolong tinggi karena berada di wilayah tropis. Mayoritas industri pengolahan ikan di Indonesia bersifat kerakyatan [3], sehingga lebih bercorak padat karya dibandingkan dengan padat modal.
Surabaya merupakan salah satu dari $17 \mathrm{kota} /$ kabupaten di Provinsi Jawa Timur yang memiliki wilayah pesisir dengan garis pantai sepanjang $37,5 \mathrm{~km}$ yang membentang dari Kecamatan Rungkut, Mulyorejo, Bulak, Asemrowo, Benowo, Krembangan, Kenjeran dan hingga Sukolilo. Meskipun sebagian besar kegiatan ekonomi Kota Surabaya berorientasi pada sektor industri dan jasa, khususnya industri skala besar, bukan berarti kegiatan ekonomi skala kecil di wilayah pesisir Surabaya tidak berkembang. Di kawasan Kenjeran, yang meliputi Kecamatan Bulak dan Sukolilo, kegiatan pengolahan ikan skala UMKM dilakukan oleh para penduduk setempat. Produk yang dihasilkan antara lain ikan asap, ikan kering, kerupuk kulit ikan, abon ikan, dan lain-lain. Beragamnya industri pengolahan ikan yang berada dalam satu kawasan ini kemudian membentuk klaster industri.

Sentra Ikan Bulak (SIB) adalah sebuah bagian dari klaster industri pengolahan ikan skala UMKM di Kawasan Kenjeran, Kota Surabaya. Fasilitas pengolahan yang didirikan oleh Pemerintah Kota Surabaya pada tahun 2009 ini memiliki kegiatan utama berupa produksi ikan asap berbahan baku ikan hasil tangkapan dari laut maupun ikan hasil budidaya. Adapun jenis ikan hasil tangkapan dari laut yang paling sering digunakan sebagai bahan baku ikan asap adalah ikan pari, ikan tengiri, dan ikan manyung. Bahan baku utama diperoleh dari nelayan setempat dan Pasar Ikan Pabean.

Pada tahun 2010, sebelum mayoritas kegiatan pengasapan ikan dipindah ke Sentra Ikan Bulak, kegiatan tersebut ditengarai menjadi penyebab menurunnya kualitas perairan di Kenjeran yang diindikasikan dari tingkat kekeruhan, padatan tersuspensi, dan logam terlarut [4]. Bahkan, berdasarkan parameter biologis,bakteri koliform berada pada angka 1,6 X $10^{5}$ MPN/100 yang berarti kondisi perairan sudah sangat tidak sehat untuk manusia yang dapat diatasi antara lain dengan mengatur pembuangan sisa pembersihan ikan [4]. Dalam industri pengolahan ikan produksi bersih merupakan salah satu cara untuk menangani limbah sehingga tidak mengganggu keseimbangan lingkungan.

Saat ini kegiatan pengolahan ikan asap di SIB ini telah menerapkan produksi bersih secara sederhana yang mana diversifikasi produk turunannya masih terbatas. Penerapan produksi bersih merupakan usaha untuk mengurangi investasi yang bernilai tinggi tetapi tidak produktif untuk sarana pengendalian pencemaran hilir dan pengelolaan limbah [2]. 
Selain menghasilkan produk utama berupa ikan asap, para pelaku usaha juga telah memanfaatkan limbah, seperti kulit pari dan arang batok, untuk meningkatkan nilai penjualan. Sedangkan limbah jeroan yang tidak dapat dijual diberikan kepada peternak lele untuk dimanfaatkan sebagai pakan lele. Oleh karena itu produksi bersih tidak hanya merupakan upaya untuk mencegah eksternalitas negatif terhadap lingkungan, tetapi juga membantu unit usaha secara ekonomis karena biaya bahan baku yang tereduksi serta dihasilkannya produk baru yang berasal dari limbah, maka seharusnya nilai penjualan dari kegiatan pengolahan ikan yang telah menerapkan produksi bersih lebih tinggi karena adanya upaya pemanfaatan limbah dibandingkan produk yang tidak mengalami proses pengolahan terlebih dahulu. Namun hingga saat ini belum pernah ada studi yang menghitung mengenai seberapa besar potensi nilai penjualan yang dapat dihasilkan oleh unit-unit usaha di Sentra Ikan Bulak yang telah menerapkan produksi bersih.

System dynamics adalah salah satu contoh alat bantu dalam mengambil keputusan yang lazim digunakan. Model simulasi kebijakan dengan menggunakan system dynamics memiliki keuntungan tersendiri, salah satunya adalah system dynamics dapat digunakan untuk mengetahui interaksi antar submodel dalam sistem, yaitu kumpulan interaksi-interaksi yang berinteraksi secara kontinu terhadap waktu, yang kompleks. Keuntungan dari melakukan simulasi sebelum suatu kebijakan diambil adalah keputusan yang tepat dapat diambil dari waktu yang tepat dengan biaya yang relatif terjangkau karena stakeholder tidak perlu melakukan eksperimen secara riil, melainkan dengan komputer.

Pada penelitian ini model dibatasi pada produksi ikan asap berbahan baku ikan pari karena pelaku usaha di Sentra Ikan Bulak telah memanfaatkan limbah dari ikan pari menjadi produk yang memiliki nilai ekonomis meskipun masih secara terbatas. Adapun system dynamics dipilih karena dapat menggambarkan interaksi antar entitas dalam jangka waktu atau periode simulasi yang dikehendaki. Output yang diharapkan dari penelitian ini adalah tersusunnya model dan prakiraan potensi nilai penjualan yang kemudian dapat digunakan para stakeholder untuk mengambil kebijakan pengembangan industri pengasapan ikan di Sentra Ikan Bulak, khususnya yang terkait dengan implementasi produksi bersih.

\section{METODE}

Tahapan yang dilalui untuk menghasilkan model ini terbagi menjadi 3 (tiga), yaitu: (1) menentukan batasan sistem; (2) menyusun model dengan system dynamics; (3) menyajikan hasil simulasi dari model system dynamics yang telah disusun. Untuk metode pengumpulan data, penulis menggunakan baik survei primer maupun sekunder. Survei primer yang dilakukan meliputi pengumpulan data melalui kuesioner, observasi, serta tanya jawab dengan pelaku usaha. Sedangkan untuk survei sekunder, penulis melalukan studi pustaka dan survei instansional. Metode analisis yang digunakan pada tahap pertama adalah analisis deskriptif berdasarkan tanya jawab dengan pelaku usaha dan hasil observasi. Selanjutnya pada tahap kedua metode analisis yang digunakan adalah running model, uji validitas, dan verifikasi model. Running model dilakukan dengan durasi simulasi selama 1 (satu) tahun. Pada tahap terakhir penulis mengeksplorasi model yang telah disusun pada tahap sebelumnya.

\section{HASIL DAN PEMBAHASAN}

\section{A. Tahapan Proses Produksi}

Tahapan proses produksi ikan asap dimulai dengan memotong dan membersihkan ikan terlebih dahulu. Bagian dari tubuh ikan yang tidak akan diproses menjadi ikan asap dipisahkan sebagai berikut: (1) kulit ikan pari akan dijual ke pengepul untuk disamak menjadi produk lain bernilai ekonomis; (2) limbah padat lainnya seperti jeroan dan serpihan tulang diambil oleh peternak lele untuk dimanfaatkan menjadi pakan lele. Berikutnya, ikan yang telah dipotong-potong akan dicuci. Proses pencucian dilakukan minimal sebanyak 2 (dua) kali di fasilitas pencucian ikan yang terdapat di dalam SIB. Dalam 1 (satu) kali proses pencucian, volume air yang dibutuhkan untuk mencuci $10 \mathrm{Kg}$ ikan adalah $100 \mathrm{Lt}$ sehingga dapat diasumsikan bahwa setiap $1 \mathrm{Kg}$ ikan membutuhkan air sebanyak $10 \mathrm{Lt}$ untuk proses pencucian. Setelah itu proses pengasapan dapat dimulai. Lamanya proses pengasapan berkisar selama 15 menit hingga warna daging ikan berubah menjadi kuning keemasan. Perlu diketahui juga bahwa ikan pari yang telah diolah dengan proses pengasapan mengalami penyusutan bobot sebesar 10\% [5] Media pengasapan yang digunakan adalah batok kelapa yang berwarna kecoklatan. Sisa pengasapan ini akan menghasilkan arang batok yang dapat dijual.

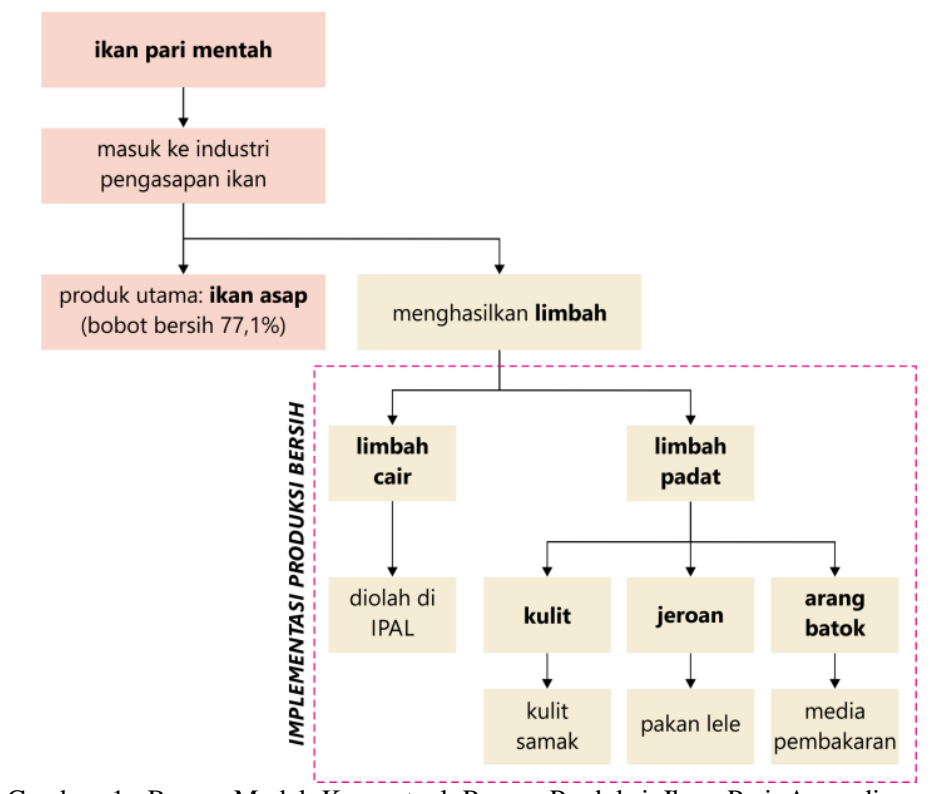

Gambar 1. Bagan Model Konseptual Proses Produksi Ikan Pari Asap di Sentra Ikan Bulak.

(Sumber: Hasil Analisis, 2017)

\section{B. Causal Loop Diagram}

"Laju tangkapan" memiliki tanda panah dengan tanda positif (+) di ujung panah yang mengarah pada "volume tangkapan". Artinya, semakin tinggi laju tangkapan ikan pari maka volume tangkapan ikan pari yang diperoleh pun semakin banyak. Ikan pari yang tertangkap ini dapat dijual sebagai produk mentah ("produk mentah") dan ada yang 
didistribusikan menjadi bahan baku ("volume bahan baku") industri pengasapan ikan pari skala UMKM di Sentra Ikan Bulak (SIB).

Untuk ikan pari yang menjadi bahan baku industri pengasapan di SIB, semakin banyak volume bahan baku maka tentu semakin banyak produk ikan asap ("volume ikan asap") yang dihasilkan. Selain itu, volume bahan baku juga berbanding lurus terhadap volume air bersih yang digunakan untuk proses pencucian ("volume air bersih). Kenaikan volume bahan baku juga berdampak terhadap media pengasapan ("volume media pengasapan") yang digunakan serta limbah yang dihasilkan, yang mana terdiri atas limbah kulit ("volume limbah kulit"), limbah jeroan ("limbah jeroan"), dan limbah media pengasapan yang sudah berupa arang batok ("volume arang batok").

Nilai penjualan dari kegiatan industri pengasapan ikan pari ("nilai penjualan produk industri ikan pari") tidak hanya berasal dari penjualan produk utama ("nilai penjualan produk utama") berupa ikan asap, tetapi juga dari nilai penjualan limbah ("nilai penjualan limbah") yang memiliki nilai ekonomis, yaitu limbah kulit ("nilai penjualan limbah kulit) dan arang batok ("nilai penjualan arang batok").

Secara kumulatif total nilai penjualan ikan pari ("summary nilai penjualan ikan pari") dihitung dari nilai penjualan produk yang tidak mengalami pengolahan ("nilai penjualan produk mentah") dan nilai penjualan dari kegiatan industri pengasapan ikan pari ("nilai penjualan produk industri ikan pari").

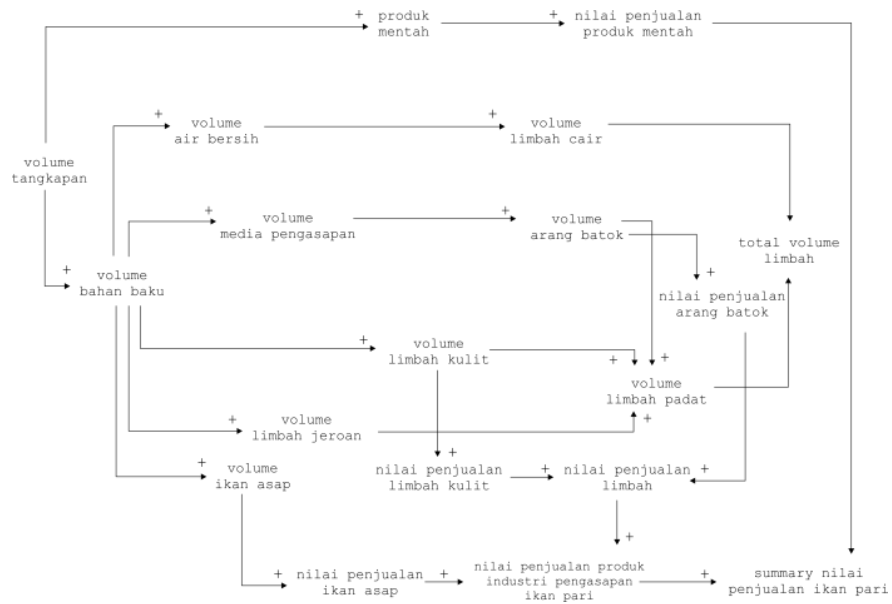

Gambar 2. Causal Loop Model.

(Sumber: Hasil Analisis, 2017)

\section{Simulasi Kegiatan Pengasapan dan Penjualan Tanpa Pengolahan}

Simulasi yang dilakukan pada model berjumlah sebanyak 9 (sembilan) skenario, yaitu: (1) 10\%:90\%; (2) 20\%:80\%; (3) $30 \%: 70 \%$; (4) 40\%:60\%; (5) 50\%:50\%; (6) 60\%:40\%; (7) 70\%:30\%; (8) 80\%:20\%; (9) 90\%:10\%. Periode simulasi yang digunakan dalam model berdurasi 1 (satu) tahun. Masingmasing skenario tersebut menunjukkan perbedaan proporsi distribusi ikan pari yang disalurkan ke industri pengasapan di SIB terhadap ikan pari yang dijual tanpa mengalami pengolahan.
Tabel 1.

Rasio Nilai Penjualan Produk Terolah dan Tidak Terolah

\begin{tabular}{cccc}
\hline Skenario & \multicolumn{2}{c}{ Nilai Penjualan (Rp) } & Rasio Nilai \\
\cline { 2 - 3 } & $\begin{array}{c}\text { Terolah dengan } \\
\text { Pengasapan }\end{array}$ & Tidak Terolah & \\
\hline $10 \%: 90 \%$ & $444.967 .611,92$ & $3.145 .249 .440,00$ & $14: 100$ \\
$20 \%: 80 \%$ & $889.935 .223,84$ & $2.795 .777 .280,00$ & $32: 100$ \\
$30 \%: 70 \%$ & $1.334 .902 .835,76$ & $2.446 .305 .120,00$ & $55: 100$ \\
$40 \%: 60 \%$ & $1.779 .870 .447,68$ & $2.096 .832 .960,00$ & $85: 100$ \\
$50 \%: 50 \%$ & $2.224 .838 .059,60$ & $1.747 .360 .800,00$ & $127: 100$ \\
$60 \%: 40 \%$ & $2.669 .805 .671,53$ & $1.397 .888 .640,00$ & $191: 100$ \\
$70 \%: 30 \%$ & $3.114 .773 .283,45$ & $1.048 .416 .480,00$ & $297: 100$ \\
$80 \%: 20 \%$ & $3.559 .740 .895,37$ & $698.944 .320,00$ & $509: 100$ \\
$90 \%: 10 \%$ & $4,004,708.507,29$ & $349.472 .160,00$ & $1146: 100$ \\
\hline \hline
\end{tabular}

(Sumber: Hasil Simulasi, 2017)

Dari hasil simulasi dengan 9 (sembilan) skenario dapat diketahui bahwa semakin banyak ikan pari yang diolah menjadi ikan asap di Sentra Ikan Bulak (SIB) maka semakin tinggi pula nilai penjualannya secara agregat, meskipun nilai penjualan dari limbah yang memiliki nilai ekonomis belum dipertimbangkan. Perhitungan nilai penjualan ikan pari asap ini telah mempertimbangkan nilai penyusutan bobot ikan pari yang mengalami proses pengasapan, yaitu sebesar 10\%.

\section{Simulasi Nilai Penjualan Secara Agregat}

Pada bagian ini hasil simulasi yang berkaitan dengan nilai penjualan dari produk utama (ikan pari asap) dan produk sampingan, yaitu limbah yang memiliki nilai ekonomis berupa limbah kulit pari dan arang batok, yang dihasilkan oleh kegiatan pengasapan di SIB ditampilkan secara agregat berdasarkan 9 (sembilan) skenario yang telah ditampilkan. Adapun limbah jeroan tidak memiliki nilai penjualan karena limbah tersebut diberikan secara cuma-cuma kepada peternak lele untuk dimanfaatkan sebagai pakan lele.

Tabel 2.

Hasil Simulasi Nilai Penjualan Secara Agregat

\begin{tabular}{cccc}
\hline \hline & $\begin{array}{c}\text { Nilai Penjualan } \\
\text { Ikan Pari Asap } \\
\text { (Rp) }\end{array}$ & $\begin{array}{c}\text { Nilai Penjualan } \\
\text { Limbah }\end{array}$ & $\begin{array}{c}\text { Akumulasi Nilai } \\
\text { Penjualan Ikan } \\
\text { Pari Asap dan } \\
\text { Limbah dengan } \\
\text { Nilai Ekonomis } \\
\text { (Rp) }\end{array}$ \\
\hline $10 \%: 90 \%$ & $444.967 .611,92$ & $260.904 .265,58$ & $705.871 .877,50$ \\
$20 \%: 80 \%$ & $889.935 .223,84$ & $521.808 .531,17$ & $1,411,743,755.01$ \\
$30 \%: 70 \%$ & $1.334 .902 .835,76$ & $782.712 .796,75$ & $2,117,615,632.51$ \\
$40 \%: 60 \%$ & $1.779 .870 .447,68$ & $1.043 .617 .062,34$ & $2,823,487,510.02$ \\
$50 \%: 50 \%$ & $2.224 .838 .059,60$ & $1.304 .521 .327,92$ & $3,529,359,387.52$ \\
$60 \%: 40 \%$ & $2.669 .805 .671,53$ & $1.565 .425 .593,50$ & $4,235,231,265.03$ \\
$70 \%: 30 \%$ & $3.114 .773 .283,45$ & $1.826 .329 .859,09$ & $4,941,103,142.54$ \\
$80 \%: 20 \%$ & $3.559 .740 .895,37$ & $2.087 .234 .124,67$ & $5,646,975,020.04$ \\
$90 \%: 10 \%$ & $4,004,708.507,29$ & $2.348 .138 .390,26$ & $6,352,846,897.55$ \\
\hline \hline
\end{tabular}

(Sumber: Hasil Simulasi, 2017)

Nilai penjualan dari limbah berbanding lurus terhadap volume ikan pari yang masuk ke industri pengasapan ikan. Secara keseluruhan nilai penjualan dari limbah memiliki kontribusi sebesar $36,96 \%$ terhadap nilai penjualan total produk industri pengasapan ikan pari.

\section{E. Validasi Model}

Uji validasi dilakukan dengan metode RMSE (root mean square error) pada entitas produk ikan asap. Melalui uji RMSE, nilai observasi dibandingkan dengan nilai hasil simulasi. 


$$
R M S E=\sqrt{\frac{\sum(\text { observasi }- \text { simulasi })^{2}}{n}}
$$

Dengan nilai observasi entitas produksi ikan asap selama 3 (tiga) hari adalah sebesar $1.048,56 \mathrm{Kg}$, sedangkan nilai prediksi entitas produksi selama 3 (tiga) hari adalah 1.122,68 $\mathrm{Kg}$, maka nilai RMSE untuk banyaknya data (n) yang dimaksud adalah 17 unit usaha adalah sebesar 17,97 Kg. Oleh karena itu, selisih error yang pada model simulasi yang dibangun pada penelitian ini memiliki nilai sebesar $17,97 \mathrm{Kg}$.

\section{F. Verifikasi Model}

Verifikasi model dilakukan untuk mengecek apakah model yang dibangun sudah dapat mensimulasikan kondisi nyata. Proses ini dilakukan secara terus menerus hingga model siap untuk disimulasikan. Cara yang digunakan penulis untuk memverifikasi model adalah dengan memastikan bahwa semua entitas sudah lengkap dan memiliki definisi serta mempunyai formula (untuk entitas yang harus memiliki formula) yang didasari oleh survei primer maupun sekunder.

\section{KESIMPULAN}

Dari hasil penelitian ini dapat diketahui bahwa penerapan produksi bersih terbukti dapat meningkatkan nilai penjualan, yang mana berdasarkan hasil perhitungan nilai penjualan limbah yang memiliki nilai ekonomis dapat meningkatkan nilai penjualan produk dari kegiatan pengasapan ikan pari di SIB sebesar $58 \%$.

Agar studi yang telah dilakukan dapat memberikan manfaat yang lebih luas, maka penulis merekomendasikan kepada pemerintah dan pelaku usaha untuk menyusun arahan peningkatan implementasi produksi bersih pada klaster industri pengolahan ikan, termasuk kolaborasi antar pelaku usaha dan peningkatan diversifikasi produk selain produk utama yang memanfaatkan daging ikan.

\section{DAFTAR PUSTAKA}

[1] P. C. Mikkel Thrane, Eskild Holm Nielsen, "CLEANER PRODUCTION IN DANISH FISH-PROCESSING EXPERIENCE, STATUS AND POSSIBLE FUTURE STRATEGIS," J. Clean. Prod., vol. 17, pp. 380-390, 2009.

[2] B. Ibrahim, Pendekatan Penerapan Produksi Bersih pada Industri Pengolahan Hasil Perikanan. Buletin Hasil Teknologi Perikanan, 2004.

[3] S. E. Heruwati, "Pengolahan Ikan Secara Tradisional: Prospek dan Peluang Pengembangan," J. Litbang Pertan., vol. 21, pp. 92-99, 2002.

[4] Badan Lingkungan Hidup Kota Surabaya, LAPORAN KEGIATAN PENGENDALIAN PENCEMARAN KAWASAN PANTAI DAN PESISIR. Badan Lingkungan Hidup Kota Surabaya, 2011.

[5] Bank Indonesia, Pola Pembiayaan Usaha Kecil Komoditas Pengolahan Ikan Pari Asap. Jakarta: Bank Indonesia, 2010. 